\title{
CLINICAL AND LABORATORY FINDINGS OF Plasmodium vivax MALARIA IN COLOMBIA, 2001
}

\author{
Marcela ECHEVERRI, Alberto TOBÓN, Gonzalo ÁLVAREZ, Jaime CARMONA \& Silvia BLAIR(1)
}

\begin{abstract}
SUMMARY
A descriptive study was carried out in 104 patients with Plasmodium vivax malaria, from the region of Turbo (Antioquia, Colombia). Clinical features and levels of hemoglobin, glycemia, serum bilirubin, alanine-aminotransferase (ALT), aspartate-aminotransferase (AST), creatinine and complete blood cell profile were established. 65\% of the studied individuals were men and their mean age was 23. Of all individuals $59 \%$ had lived in the region for $>1$ year and $91 \%$ were resident in the rural area. $42 \%$ were farmers and $35 \%$ had a history of malaria. The mean parasitaemia was 5865 parasites $/ \mathrm{mm}^{3}$. The evolution of the disease was short (average of 4.0 days). Fever, headache and chills were observed simultaneously in $91 \%$ of the cases while the most frequent signs were palmar pallor (46\%), jaundice (15\%), hepatomegaly (17\%), and spleen enlargement (12\%). Anemia was found in $39 \%$ of the women and in $51 \%$ of the men, $8 \%$ of individuals had thrombocytopaenia and $41 \%$ had hypoglycemia.
\end{abstract}

KEYWORDS: Plasmodium vivax; Clinical; Laboratory; Non-complicated; Malaria.

\section{INTRODUCTION}

Plasmodium vivax is the most commonly human malaria parasite of the four species affecting humans. Currently, this infection is endemic in many countries of Asia, South Pacific, North Africa, Middle East and South and Central America ${ }^{15}$. A significant increase on the number of cases was observed during the period $1990-1999^{26}$ reaching a total of 896000 P. vivax cases reported in America in 1999.

In Colombia, a total of 70938 cases of malaria were diagnosed in 1999 , of which $65 \%$ were $P$. vivax malaria ${ }^{8}$. In the region of Antioquia, 21009 cases of malaria were reported in 1999 , of which $82 \%$ were $P$. vivax malaria. Within this region, the municipality of Turbo reported 3409 cases of malaria $(81 \% \text { P. vivax })^{2}$.

The most commonly described clinical presentation of $P$. vivax malaria is fever, headache, chills and sweating. Some authors have made occasional reports of abdominal and osteomuscular pain, vomiting, diarrhea, hepatomegaly and splenomegaly ${ }^{19,33}$. Symptoms and clinical signs of the infection caused by $P$. vivax resemble infection caused by other species ${ }^{13,33}$ and none of the symptoms can predict a diagnosis of malaria or differentiate the infecting species, as it has been proposed in cases of infection in children in low endemic areas ${ }^{18}$.

There has been an increase in the number of reports of complications during $P$. vivax infection, including cerebral malaria and seizures ${ }^{31,32}$, pulmonary edema ${ }^{9,23,28}$, respiratory distress syndrome ${ }^{5}$, kidney failure ${ }^{1}$, and death $^{4,16}$. In Colombia, cases of acute respiratory distress syndrome and death have been reported in the last few years ${ }^{22}$ as well as cerebral malaria, thrombocytopaenia, severe anemia and kidney, liver and lung damage ${ }^{11}$.

As may be noted in these works, in the last few years the presence of clinical complications caused by $P$. vivax has been reported and we have received field reports of deaths caused by this species, we also ignore its clinical and laboratorial behavior. A retrospective study carried out by us ${ }^{11}$ confirms that there are no recent clinical studies about the behavior of $P$. vivax in Colombia and we proposed the present work with the aim of elucidating the profile of complications that are produced in a high number of patients and to design strategies for the Ministry of Health in its treatment.

\section{MATERIALS AND METHODS}

Sample selection: The descriptive longitudinal study was carried out in patients with $P$. vivax malaria, in the municipality of Turbo (Antioquia, Colombia). The sample was constituted by patients being attended to at the local hospital from February to March, 2001. They were included in the study as they attended to at the malaria diagnosis facility; men and women were selected according to the inclusion criteria. The protocol was approved by the ethical commission of the University of Antioquia.

The size of the sample was calculated based on the following equation $^{21}$ :

$$
n=\frac{N \times Z^{2} \times p \times(1-p)}{\left(N \times e^{2}\right)+\left(Z^{2} \times p \times(1-p)\right)} \Rightarrow n=\frac{4589 \times 1.96^{2} \times 0.5 \times(0.5)}{\left(4589 \times 0.1^{2}\right)+\left(1.96^{2} \times 0.5 \times(0.5)\right)}=94
$$


Where: $\mathrm{n}=$ sample size; $\mathrm{N}=$ population total, i.e., cases of $P$. vivax malaria in 2000 in Turbo; $\mathrm{p}=$ proportion of $P$. vivax malaria presenting a specific symptom or sign; $\mathrm{e}=$ sampling error; $\mathrm{Z}=$ confidence level.

Considering $10 \%$ losses, a total 104 patients were included in the study.

Malaria diagnosis: Diagnosis, species and number of parasites were determined by Giemsa stained thick blood smears following WHO recommendations ${ }^{17}$.

Clinical evaluation: After the diagnosis, anamnesis and clinical evaluation were done by a physician who followed a previously designed protocol and recorded the information in a designed form. The evaluation included body weight, assessment of blood pressure, heart and respiratory rates, axillary's temperature, systems examination and description of the general condition of the patient.

Laboratory tests: At the enrollment in the study and regardless of the fasting period, $12 \mathrm{ml}$ of venous blood was obtained from each patient. The level of Alanine aminotransferase (ALT) and Aspartate aminotransferase (AST), direct and indirect bilirubin, creatinine, glycemia and complete blood cell profile were assessed. Normal reference values of hemoglobin were based on the Wintrobe's criteria ${ }^{27}$ with some modifications introduced by us.

Inclusion criteria: All the following had fulfilled: a. >1 year age; $b$. $P$. vivax unique infection; c. Permanent residence in the study area; $\mathrm{d}$. History of fever during the present episode; e. Informed consent (signed by the patient or his/her parents if underage).

Exclusion criteria: To have at least one of the following: a. Severe undernourishment; b. Pregnancy; c. Febrile disease associated; d. History of antimalarial drug intake during the present disease.

Statistical analysis: The programs EpiInfo 6.04 and Stat-Graphics 3.1 were used. The following analyses were carried out:

a) Evaluation of the association of two non-metric variables with the chi square test $\left(\mathrm{X}^{2}\right)$ i.e.: appearance/absence of a syndrome and its relation with sex or age group; anemia (yes or not) and occupation.

b) Comparison of average between independent groups using the Kruskal and Wallis $\mathrm{H}$ test (non parametric anova) i.e.: parasitaemia and age group, bilirubin or enzyme ALT or AST and jaundice (yes or not).

c) Simple lineal correlation of metric variables, i.e.: hemoglobin in parasitaemia; enzymes ALT or AST in parasitaemia; bilirubin in enzymes ALT or AST.

\section{RESULTS}

104 ambulatory patients were studied with $P$. vivax diagnosis. Age fluctuated between 2 and 75 years old, with 23.2 average (Medium = 20.0). 32 patients were children ( $<15$ years old), 22 of them $(69 \%)$ were male, 72 were adults and 46 of them $(64 \%)$ were male. All patients lived in Turbo, $91 \%$ in rural areas and the time of residence in $41 \%$ was $\leq 12$ months. $42 \%$ carried out agricultural works and during the past year $35 \%$ had malaria (72\% P. vivax and $28 \%$ P. falciparum).
The average body weight of children was $24.9 \mathrm{~kg}$ (SD 10.4) and of adults $59.5 \mathrm{~kg}$ (SD 15.0), no gender differences were observed in both groups ( $p>0.10)$. In children, the correlation coefficient between weight and age was 0.84 . Mean parasitaemia was 5865 parasites $/ \mathrm{mm}^{3}$ (SD 6307). The evolution time of the disease from the start of the symptoms to the moment of clinical evaluation was from 1 to 22 days (average $=5$ days, SD 4.2 days; $95 \%$ CI: 4.1 to 6.1 days).

Main symptoms observed during the clinical disease are shown in Table $1.91 \%$ of the patients had from 5 to 7 symptoms and the most frequent were: fever (99\%), headache (99\%) and chills (91\%). This triad was positive in $91 \%$ of the patients. During the clinical examination, $98 \%$ of the patients were fully alert and $2 \%$ lethargic, $65 \%$ had normal temperature $\left(<37.5^{\circ} \mathrm{C}\right)$. Mean values of their vital signs are indicated in Table 2. Palpable liver and spleen were presented simultaneously in $7 \%$ and a significant association between these two signs was established ( $\mathrm{p}$ $<0.0000)$.

Table 1

Symptoms and clinical signs at any stage of the illness in 104 patients with $P$. vivax malaria

\begin{tabular}{lcc}
\hline & Number of patients & $\%$ \\
\hline Symptoms & 103 & \\
Fever & 103 & 99 \\
Headache & 95 & 99 \\
Chills & 81 & 91 \\
Sweating & 60 & 78 \\
Osteomuscular pain & 41 & 58 \\
Vomit & 35 & 39 \\
Abdominal pain & 34 & 34 \\
Dizziness & 14 & 33 \\
Diarrhea & & 13 \\
\hline Signs & 48 & \\
Hand pallor & 16 & 46 \\
Jaundice & 18 & 15 \\
Liver enlargement & 10 & 17 \\
Spleen enlargement & & \\
\hline
\end{tabular}

Table 2

Vital signs at the medical evaluation in 104 out-patients with $P$. vivax malaria ${ }^{(1)}$

\begin{tabular}{|c|c|c|c|}
\hline $\operatorname{Sign}^{(2)}$ & Mean & $\mathrm{DE}$ & C. I. \\
\hline Hearth rate & 97 & 22 & $93.3-113.4$ \\
\hline Respiratory rate & 27 & 11 & $24.3-27.7$ \\
\hline Diastolic pressure & 66 & 12.4 & $63.9-69.2$ \\
\hline Systolic pressure & 111 & 12.8 & $108.3-113.9$ \\
\hline Arterial mean pressure & 81 & 11.5 & $78.9-83.9$ \\
\hline Temperature & 37.6 & 1.2 & $37.4-37.8$ \\
\hline
\end{tabular}

(1) mean: arithmetic mean; SD: standard deviation; CI: 95\% mean confidence interval; (2) Hearth and respiratory rates by minute; arterial blood pressure: $\mathrm{Hg}$ $\mathrm{mm}$.; temperature ${ }^{\circ} \mathrm{C}$ 


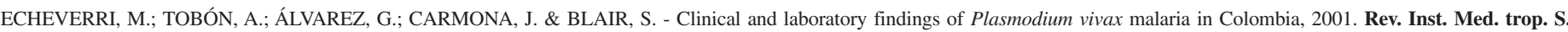
Paulo, 45(1):29-34, 2003.

Mean parasitaemia in patients exhibiting 1-4 symptoms was 3371 $(\mathrm{SD} \pm 3504)$ parasites $/ \mathrm{mm}^{3}$, for patients with 5-7 symptoms it was 5776 $(\mathrm{SD} \pm 6425)$ and for patients with $8-10$ symptoms it was $8675( \pm 6298)$.

Laboratory findings are shown in Tables 3, 4, and 5. We observed high levels of direct bilirubin in $6 \%$ of the patients and high indirect bilirubin in $20 \%$ of them.

Glycemia was $<55 \mathrm{mg} / \mathrm{dL}$ in $31 \%(11 / 35)$ of females, and $>105 \mathrm{mg} /$ $\mathrm{dL}$ in $11 \%(4 / 35)$ of them. $47 \%$ of the men (31/66) presented lower values than the threshold and $17 \%(11 / 66)$ above. In total $41 \%$ of the patients were hypoglycemic and $15 \%$ hyperglycemic. Hypoglycemia affected equally men and women, children and adults and was not associated to specific clinical manifestations $(\mathrm{p}>0.05)$. Mean glycemia values in hypoglycemic individuals was significantly different $(\mathrm{p}<$ 0.0001 ) from values in the rest of the individuals $(44.8$ and $79.5 \mathrm{mg} / \mathrm{dL}$ respectively). Glycemia levels were independent from parasitaemia,
Table 3

Laboratory results in 102 out-patients with malaria by $P$. vivax ${ }^{(1)}$

\begin{tabular}{lccc}
\hline Item & $\bar{X} \pm S D$ & CI & Reference value \\
\hline Glycemia $(\mathrm{mg} / \mathrm{dL})$ & $79.7 \pm 38$ & $67.0-93.4$ & $65-105$ \\
in women & & & \\
Glycemia in men & $83.0 \pm 41$ & $73.0-92.9$ & $75-110$ \\
Platelets $\left(10^{3} / \mathrm{mm}^{3}\right)$ & $269 \pm 85$ & $252.2-285.7$ & $130-400$ \\
Erythrocytes $\left(10^{6} / \mathrm{mm}^{3}\right)$ & $4.5 \pm 1.1$ & $4.3-4.8$ & $4.7-6.1$ \\
Leukocytes $\left(10^{3} / \mathrm{mm}^{3}\right)$ & $6.2 \pm 2.5$ & $5.7-6.7$ & $4.8-10.8$ \\
Lymphocytes $(\%)$ & $32.8 \pm 12.8$ & $30.4-35.4$ & $20.5-51.1$ \\
Neutrophils (\%) & $57 \pm 13$ & $54.8-59.9$ & $42.2-75.2$ \\
Monocytes (\%) & $4 \pm 2.7$ & $3.6-4.7$ & $1.7-9.3$ \\
Eosinophils (\%) & $3 \pm 2.9$ & $2.91-4.0$ & $2.0-5.0$ \\
Parasitaemia & $5865 \pm 6307$ & $4653-7077$ & - \\
\hline
\end{tabular}

(1) mean: arithmetic mean; SD: standard deviation; CI: $95 \%$ mean confidence interval.

Table 4

Sex and age hemoglobin values $(\mathrm{g} / \mathrm{dL})$ in 104 outpatients with malaria by $P$. vivax ${ }^{(1)}$

\begin{tabular}{|c|c|c|c|c|c|}
\hline Age & No. & $\begin{array}{c}\text { Hemoglobin } \\
\bar{X} \pm S D\end{array}$ & CI & $\begin{array}{l}\text { Anemia } \\
\text { No. }(\%)\end{array}$ & $\begin{array}{l}\text { Reference value } \\
\text { (lower value) }\end{array}$ \\
\hline $\begin{array}{l}\text { Women } \\
2-6 \\
7-12 \\
13-18 \\
>18\end{array}$ & $\begin{array}{c}3 \\
5 \\
9 \\
19\end{array}$ & $\begin{array}{l}10.3 \pm 1.9 \\
11.5 \pm 1.2 \\
12.3 \pm 1.3 \\
13.9 \pm 4.0\end{array}$ & $\begin{array}{r}8.1-12.4 \\
10.5-12.5 \\
11.4-13.1 \\
12.2-15.6\end{array}$ & $\begin{array}{l}2(66) \\
2(40) \\
4(44) \\
6(32)\end{array}$ & $\begin{array}{l}11.5 \\
11.5 \\
12.0 \\
12.0\end{array}$ \\
\hline $\begin{array}{l}\text { Men } \\
2-6 \\
7-12 \\
13-18 \\
>18\end{array}$ & $\begin{array}{c}2 \\
17 \\
8 \\
40\end{array}$ & $\begin{array}{c}9.4 \pm 1.0 \\
12.1 \pm 4.6 \\
12.6 \pm 1.9 \\
14.1 \pm 3.5\end{array}$ & $\begin{array}{r}8.2-10.6 \\
9.9-14.2 \\
10.2-15.0 \\
13.0-15.2\end{array}$ & $\begin{array}{c}2(100) \\
11(65) \\
5(62) \\
16(40)\end{array}$ & $\begin{array}{l}11.5 \\
11.5 \\
12.5 \\
13.0\end{array}$ \\
\hline
\end{tabular}

(1) Mean arithmetic mean; SD: standard deviation; CI: $95 \%$ mean confidence interval.

Table 5

Age and sex bilirubin (mg/dL), creatinine (mg/dL), ALT and AST (UI/L) values in 104 outpatients with malaria by P. vivax ${ }^{(1)}$

\begin{tabular}{|c|c|c|c|c|c|c|}
\hline Item & & $\bar{X} \pm S D$ & & $\mathrm{CI}$ & \multicolumn{2}{|c|}{ Reference value ${ }^{(2)}$} \\
\hline Direct bilirubin $(\mathrm{mg} / \mathrm{dL})$ & & $0.24 \pm 0.13$ & & $21-0.26$ & \multicolumn{2}{|c|}{$0.00-0.30$} \\
\hline Indirect bilirubin $(\mathrm{mg} / \mathrm{dL}$ & & $0.78 \pm 0.48$ & & $69-0.88$ & \multicolumn{2}{|c|}{$0.00-1.10$} \\
\hline Women & \multicolumn{2}{|c|}{$1-10$ years } & \multicolumn{2}{|c|}{$>11$ years } & & \\
\hline Item & $\bar{X} \pm$ D.S. & $\mathrm{CI}$ & $\bar{X} \pm$ D.S. & $\mathrm{CI}$ & & \\
\hline Creatinine & $0.5 \pm 0.82$ & $0.370-0.63$ & $0.79 \pm 0.12$ & $0.745-0.83$ & & \\
\hline AST & $46 \pm 14.76$ & $19.50-66.49$ & $34 \pm 17.82$ & $27.49-40.56$ & & \\
\hline ALT & $24 \pm 5.12$ & $16.09-32.40$ & $26.5 \pm 12.8$ & $21.81-31.21$ & & \\
\hline Men & \multicolumn{2}{|c|}{$1-10$ years } & \multicolumn{2}{|c|}{ 11-14 years } & \multicolumn{2}{|c|}{$>15$ years } \\
\hline Item & $\bar{X} \pm D . S$. & CI & $\bar{X} \pm D . S$ & CI & $\bar{X} \pm D . S$. & CI \\
\hline Creatinine & $0.54 \pm 0.09$ & $0.48-0.59$ & $0.68 \pm 0.135$ & $0.56-0.81$ & $0.94 \pm 0.30$ & $0.86-1.03$ \\
\hline AST & $35.9 \pm 19.09$ & $24.9-6.9$ & $29.4 \pm 7.2$ & $22.7-36.1$ & $38.3 \pm 19.6$ & $32.4-44.1$ \\
\hline ALT & $24.9 \pm 11.5$ & $18.3-31.6$ & $24.7 \pm 8.6$ & $16.8-32.7$ & $25.0 \pm 7.6$ & $22.8-27.3$ \\
\hline
\end{tabular}

(1) Mean arithmetic mean; SD: standard deviation; CI: 95\% mean confidence interval; (2) Reference values:

\begin{tabular}{|c|c|c|c|c|c|c|}
\hline Women: & $1-10$ years & $>10$ years & Men: & $1-10$ years & $10-14$ years & $>14$ years \\
\hline Creatinine & $0.5-0.9$ & $0.7-1.2$ & & $0.5-0.8$ & $0.6-1.0$ & $0.8-1.5$ \\
\hline ALT & $10-35$ & $9-52$ & & $10-35$ & $10-55$ & $21-72$ \\
\hline AST & $15-40$ & $10-30$ & & $15-40$ & $15-40$ & $17-59$ \\
\hline
\end{tabular}


number of days of the disease, hemoglobin, systolic and mean arterial blood pressure $(r<0.15$ and $\mathrm{p}>0.05)$. However, the age of the patients was slightly correlated with hypoglycemia $(r=0.30 ; p>0.05)$.

Creatinine and ALT levels were normal in all individuals. AST levels were high in $36 \%$ of the women over 10 years of age and in $30 \%$ of the men under 11 years old.

Anemia was observed in 34 males and 14 females and in all cases the frequency of anemia was inversely correlated with age (Table 4). According to age groups, hemoglobin mean values exhibited important differences, in women ( $\mathrm{KW}=7.007$; $\mathrm{df}=3 ; \mathrm{p}=0.071664)$ and in men $(\mathrm{KW}=14.439 ; \mathrm{df}=3 ; \mathrm{p}=0.002365)$. There were not significant differences among male and female hemoglobin values within each age group ( $p>0.05)$. In children, anemia was neither associated to sex, occupation nor malaria antecedents $(\mathrm{p}>0.05)$. There is a very slight correlation between the hemoglobin level and time of residence in the area $(r=-0.13)$, age $(r=0.37)$ and parasitaemia $(r=0.40)$.

The platelet average was $269000 / \mathrm{mm}^{3}$. Thrombocytopaenia was present in 8 adult patients (8\%), with mean hemoglobin of $15 \mathrm{~g} / \mathrm{dL}$ and a mean parasitaemia $6170 / \mathrm{mm}^{3}$; hepatomegaly was present in 3 and hepatoesplenomegaly in one case.

The white cell count was abnormal in $34 \%$ of the patients: $29 \%$ leucopenia and 5\% leucocytosis; the average of leukocytes was of 6200/ $\mathrm{mm} 3$. The lymphocytopenia, neutropenia, monocytopenia and eosinopenia prevailed on their respective excess conditions, being in $17 \%, 13 \%, 16 \%$ and $30 \%$ of the cases. Eosinopenia and eosinophilia were the most common alterations (30\% and $19 \%$ respectively).

\section{DISCUSSION}

$91 \%$ of the patients lived in rural areas; the population was highly exposed to malaria considering the annual parasite index (API) of 30.5 per thousand observed during 1999, estimated over 111578 residents 7 . $35 \%$ of the patients had a history of malaria infection during the previous year. The period of evolution of the disease was relatively short (average: 5 days).

The triad fever, headache and chills, was present in $91 \%$ of the patients. This confirms previous observations made by us in Antioquia, Colombia ${ }^{11}$ and, it also agrees with classic findings ${ }^{13,33}$ and with recent studies made by several authors in different geographic regions (Brazil ${ }^{10}$, India $^{6,12}$, Thailand ${ }^{18}$, Saudi Arabia ${ }^{19}$, Gambia $^{24}$, Singapore ${ }^{25}$, Australia ${ }^{29}$ ) who also reported the presence of splenomegaly, hepatomegaly and anemia as the most common signs in vivax malaria.

The frequency of vomiting was age-dependent and was between $15 \%$ and $67 \%$ in the above mentioned studies. A frequency of this symptom in $48 \%$ of individuals was reported in Saudi Arabia ${ }^{19}$, while in Gambia ${ }^{24}$ it was $67 \%$. In these two studies carried out in children under five years old, the presence of vomiting was the second most common symptom. Children under 14 year-old from Pará-Brazil ${ }^{10}$ had a frequency of $24 \%$. In our study we observed $50 \%$ frequency of vomiting in children and $35 \%$ in adults. Furthermore, in the present study the frequency of diarrhea was $12.5 \%$ in children, which is in accordance with other authors who reported $13 \%$ frequency in children from Pará-Brazil ${ }^{10}$.
No statistically significant difference was observed among parasitaemia and number of symptoms maybe due to the reduced size in two of the three compared groups $(\mathrm{KW}=5.766, \mathrm{~g} l=2, \mathrm{p}=0.055971)$.

The frequency of clinical signs was significantly lower than the frequency of symptoms, which confirms what is already well known. It has been reported that patients with acute non-complicated malaria have few abnormal physical signs, including a mild anemia and a palpable spleen $^{33}$. However, besides the high fever, signs such as pallor, coluric urine, hepatomegaly, splenomegaly, thrombocytopaenia and low hemoglobin were present in $18 \%$ to $64 \%$ of the patients in the cited studies and were predominant in children. In our study, hepatomegaly and splenomegaly were present in $17 \%$ and $10 \%$ respectively and the latter was more frequent in children $(22 \%)$, significantly different between children and adults (Fisher's exact test, $\mathrm{p}=0.0093496$ ). However, differences have been observed concerning other findings in children under 15 years old. While in Brazil ${ }^{10}$, splenomegaly was detected in $46 \%$ of the children, in Surat-India ${ }^{6} 13 \%$ were positive and in ShokloThailand $^{18}$ (2-15 year-old children) $8 \%$ of $P$. vivax and $25 \%$ of $P$. falciparum infected patients had spleen enlargement. Hepatomegaly was positive in $29 \%$ of children patients in Brazil $^{10}$, in $4 \%$ in Surat $^{6}$, in $3 \%$ for $P$. vivax and in $13 \%$ for P. falciparum in Shoklo ${ }^{18}$, and in $28 \%$ among us. We found hepato-splenomegaly in $16 \%$ of 32 children and $3 \%$ of 72 adults and there was a significant association in both groups between this finding and malaria (Fisher's exact test, $\mathrm{p}<0.041$ ). It is striking the splenomegaly-hepatomegaly ratio observed by us is much lower than the one reported by others (0.8 vs. 1.6 in Surat $^{6}, 2.4$ in Shoklo ${ }^{18}, 3.2$ in Pará, Brazil $\left.{ }^{10}\right)$, with the exception of $\operatorname{Gambia}^{24}(0.9)$. Our data confirms a lack of association between hepatomegaly and jaundice $(p>0.05)$ or increased ALT or AST ( $\mathrm{p}>0.05)$.

Thrombocytopaenia is a common finding in $P$. falciparum and $P$. vivax infections and the cause of it remains unclear ${ }^{30} .8 \%$ of our patients evidenced this. Previously, we have reported $36 \%$ thrombocytopaenia in 281 hospitalized adults with malaria in Medellín, associated in a similar way to $P$. vivax and $P$. falciparum $^{11}$. The presence of thrombocytopaenia is not related to the severity of infection and the association with bleeding or disseminated intravascular coagulation syndrome (DIC) is uncommon $^{30}$. Bleeding (epistaxis and petechiae) was observed in this study in 2 of 8 thrombocytopenic patients, which confirms previous findings ${ }^{11}$. Presence of thrombocytopaenia has been reported in $71 \%$ of the malarial cases in Melbourne ${ }^{29}$, while in Calcutta HAZRA et al. ${ }^{12}$, 1998 , reported DIC in $3 \%$ of $P$. falciparum infected patients but in none by $P$. vivax.

Along with glycemia changes, the most frequent abnormal findings in this study were anemia (39\% in women and 51\% in men; $69 \%$ in children and $56 \%$ in adults). In a different study on blood parameters during malaria infection, carried out in El Bagre (Colombia), we found that $30 \%$ of $1-14$ year-old children and $25 \%$ of adults had anemia (febrile non malaria controls were anemic in $10 \%$ and $20 \%$, respectively $)^{3}$.

Anemia in malaria is due to the destruction of infected erythrocytes and to bone marrow suppression ${ }^{13,14}$, but in highly endemic areas malnutrition and intestinal parasite infections (mainly uncinariasis and strongyloidiasis) boost this problem. DA SILVA VENTURA et al. (1999), reported $71 \%$ of intestinal parasitism in Brazil ${ }^{10}$ among 0-14 year-old children with vivax malaria, $19 \%$ had ancylostomiasis, and $100 \%$ of 
those with helminthiasis had anemia. As in general, malnutrition affects more children than adult population, and mainly protein-caloric malnutrition is a widely spread problem in Colombia, we exclude severe undernourished children from the present study. In the studied children we found a high correlation between weight and age $(r=0.84)$, this together with a clinical examination led us to exclude severe malnutrition. In summary, protein-caloric malnutrition and intestinal parasite infections can not be discarded as the cause of anemia in this study.

In this study, $41 \%$ of the patients had hypoglycemia. This is the most common silent finding in African children with severe malaria ${ }^{20}$. In Medellín, we have found glycemia $<61 \mathrm{mg} / \mathrm{dL}$ in $3 \%(\mathrm{n}=291)$ of hospitalized patients with vivax or falciparum malaria ${ }^{11}$. A total of $41 \%$ of the patients with hypoglycemia is high considering that our study was carried out in non-hospitalized and non-complicated patients. Furthermore, this finding is very concerning as it was observed regardless of the fasting period. However, the presence of a hypoglycemic syndrome (headache, sweating and faintness with glycemia $<55 \mathrm{mg} / \mathrm{dL}$ ) was not observed in any patient.

In conclusion, acute febrile $P$. vivax malaria (in outpatients of the municipality of Turbo, Antioquia), exhibits a mild clinical pattern, where the most frequent sign is the presence of anemia, which is more intense in $<15$ year-olds, followed by asymptomatic hypoglycemia. Malnutrition and intestinal parasitism might account for the high frequency of anemia.

\section{RESUMEN}

\section{Características clínicas y de laboratorio de la malaria por Plasmodium vivax, Colombia 2001}

Se realizó un estudio descriptivo con 104 enfermos de malaria por Plasmodium vivax, en Turbo (Antioquia, Colombia). Se evaluaron las características clínicas y los niveles de hemoglobina, glicemia, bilirrubina sérica, ALT, AST, creatinina y hemograma completo. Los hombres representaron el $65 \%$ del grupo, la edad promedio fue 23 años, el 59\% tuvo más de un año de residir en el lugar, el $91 \%$ residían en zona rural, el $42 \%$ realizaba trabajos agrícolas y el $35 \%$ tenía antecedentes de malaria. La parasitemia promedio fue de 5865 parásitos $/ \mathrm{mm}^{3}$. La evolución de la enfermedad fue corta (mediana de 4,0 días). Fiebre, cefalea y escalofrío estuvieron simultáneamente en $91 \%$ de los casos y los signos más frecuentes fueron palidez palmar (46\%), ictericia (15\%), hepatomegalia (17\%) y esplenomegalia (12\%). La anemia se encontró en el $39 \%$ de las mujeres y en el $51 \%$ de los hombres, y el $8 \%$ presentó trombocitopenia. Los niveles séricos de bilirrubinas directa e indirecta, de enzimas ALT y AST y de creatinina se encontraron, en general, normales. El $41 \%$ de los pacientes tuvo hipoglicemia.

\section{ACKNOWLEDGEMENTS}

We are very grateful with the University of Antioquia for their financial support, to the community of Turbo for their participation in the study, to directives of the local hospital of Turbo and the operative personnel of malaria for their logistical support, and to Dr. Amanda Maestre for the revision of the translated text.

\section{REFERENCES}

1. AHMAD, S.H.; DANISH, T.; FARIDI, M.M. et al. - Renal function in acute malaria in children. J. trop. Pediat., 35: 291-294, 1989.

2. ANTIOQUIA, DIRECCIÓN SECCIONAL DE SALUD - Malaria. Rev. epidem. Antioquia, 25: 130-131, 2000.

3. BLAIR, S.; ÁLVAREZ, G. \& CAMPUZANO, G. - Relación entre anemia y malaria en una población rural colombiana. Bol. Direcc. Malar., 37: 7-13, 1997.

4. CANADA HEALTH PROTECTION BRANCH, CDC LABORATORY - Canada Communicable Disease Report, 25, 6, year 1999. www.hc-sc.gc.ca/hpb/cdc. Consulted January 2001.

5. CARLINI, M.E.; WHITE, Jr., A.C. \& ATMAR, R.L. - Vivax malaria complicated by adult respiratory distress syndrome. Clin. infect. Dis., 28: 1182-1183, 1999.

6. CHANDRAMOHAN, D.; CARNEIRO, I.; KAVISHWAR, A. et al. - A clinical algorithm for the diagnosis of malaria: results of an evaluation in an area of low endemicity. Trop. Med. Int. HIth., 6: 505-510, 2001.

7. COLOMBIA. DEPARTAMENTO ADMINISTRATIVO NACIONAL DE ESTADÍSTICA, DANE - Proyecciones municipales de población por area, 1995-2005. Bogotá, DANE, 1998.

8. COLOMBIA. MINISTERIO DE SALUD - Situación de salud en Colombia. Indicadores básicos. Bogotá, Minsalud; OMS/OPS, 2000. p. 16.

9. CURLIN, M.E.; BARAT, L.M.; WALSH, D.K. \& GRANGER, D.L. - Noncardiogenic pulmonary edema during vivax malaria. Clin. infect. Dis., 28: 1166-1167, 1999.

10. DA SILVA VENTURA, A.M.R.; PINTO, A.Y.N.; SILVA R.S.V. et al. - Malaria por Plasmodium vivax em crianças e adolescentes: aspectos epidemiológicos, clínicos e laboratoriais. J. Pediat. (Rio de J.), 75: 187-194, 1999.

11. GONZÁLEZ, L.; GUZMÁN, M.; CARMONA, J.; LOPERA, T. \& BLAIR, S. Características clínico-epidemiológicas de 291 pacientes hospitalizados por malaria en Medellín (Colombia). Acta méd. colomb., 25: 163-170, 2000.

12. HAZRA, B.R.; CHOWDHURY, R.S.; SAHA, S.K.; GHOSH, M.B. \& MAZUMDER, A.K. - Changing scenario of malaria: study at Calcutta. Indian J. Malar., 35: 111116, 1998.

13. KRAUSE, P.J. - Paludismo (Plasmodium). In: BEHRMAN, R.E.; KLIEGMAN, R.M. \& JENSON, H.B. Nelson: tratado de Pediatría. 16. ed. México, McGraw HillInteramericana, 2001. v.1, p.1050-1054.

14. KURTZHALS, J.A., RODRIGUES, O.; ADDAE, M. et al. - Reversible suppression of bone marrow response to erythropoietin in Plasmodium falciparum malaria. Brit. J. Hemat., 97: 169-174, 1997.

15. LI, J.; COLLINS, W.E.; WIRTZ, R.A. et al. - Geographic subdivision of the range of the malaria parasite Plasmodium vivax. Emerg. infect. Dis., 7: 35-42, 2001.

16. LOBOVSKA, A.; RUBIK, I.; HOLUB, M. \& SELINGER, P. - The first death from tertian malaria in the Czech Republic. Cas. Lék. ces., 138: 52-55, 1999.

17. LÓPEZ-ANTUÑANO, F.J. \& SCHMUNIS, G., ed. - Diagnóstico de malaria. Washington, OPS-OMS, 1998. p. 143. (Publicación Cientifica, 512).

18. LUXEMBURGER, C.; NOSTEN, F.; KYLE, D.E. et al. - Clinical features cannot predict a diagnosis of malaria or differentiate the infecting species in children living in an area of low transmission. Trans. roy. Soc. trop. Med. Hyg., 92: 45-49, 1998.

19. MALIK, G.M.; SEIDI, O.; EL-TAHER, A. \& MOHAMMED, A.S. - Clinical aspects of malaria in the Asir region, Saudi Arabia. Ann. Saudi Med., 18: 15-17, 1998. 
20. MARSH, K. - Clinical features of malaria. In: WAHLGREN, M. \& PERLMANN. P. Malaria. Molecular and clinical aspects. Amsterdam, Harwood Academic Publ., 1999. p. $103-104$

21. MARTÍNEZ-BENCARDINO, C. - Estadística y muestreo. 9. ed. Bogotá, Ed. Ecoe, 1999. p. 886

22. MARTÍNEZ, O. - Síndrome de dificultad respiratoria aguda en malaria por Plasmodium vivax. Acta méd. colomb., 21: 146-150, 1996

23. MUNTEIS, E.; MELLIBOVSKY, L.; MÁRQUEZ, M.A. et al. - Pulmonary involvement in a case of Plasmodium vivax malaria. Chest, 111: 834-835, 1997.

24. O`DEMPSEY, T.J.; McARDLE, T.F.; LAURENCE, B.E. et al. - Overlap in the clinical features of pneumonia and malaria in African children. Trans. roy. Soc. trop. Med. Hyg., 87: 662-665, 1993.

25. OH, H.M.; KONG, P.M. \& SNODGRASS, I. - Imported malaria in a Singapore hospital: clinical presentation and outcome. Int. J. infect. Dis., 3: 136-139, 1999.

26. PAN-AMERICAN HEALTH ORGANIZATION, PAHO (OPS) - Situación de los programas de malaria en las Américas. Bol. Epidem. Org. panamer. Salud, 22: 1014, 2001.

27. PERKINS, S.L. - Normal blood and bone marrow values. Appendix. In: LEE, G.R.; FOERSTER, J.; LUKENS, J. et al. Wintrobe's clinical Hematology. 10. ed. Philadelphia, Williams \& Wilkins, 1999. v. 2, table A-17, p. 2742-2743.
28. PUKRITTAYAKAMEE, S.; CHANTRA, A.; VANIJANONTA, S. \& WHITE, N.J. Pulmonary oedema in vivax malaria. Trans. roy. Soc. trop. Med. Hyg., 92: 421422, 1998 .

29. ROBINSON, P.; JENNEY, A.W.; TACHADO, M. et al. - Imported malaria treated in Melbourne, Australia: epidemiology and clinical features in 246 patients. J. Travel Med., 8: 76-81, 2001.

30. SORABJEE, J.S. - Haematological changes in malaria. Bombay Hosp. J., 38: 5-8, 1996

31. VALECHA, N.; BAGGA, A.; CHANDRA, J. \& SHARMA, D. - Cerebral symptoms with $P$. vivax malaria. Indian Pediat., 29: 1176-1178, 1992.

32. WATTANAGOON, Y.; SRIVILAIRIT, S.; LOOAREESUWAN, S. \& WHITE, N.J. Convulsions in chilhood malaria. Trans. roy. Soc. trop. Med. Hyg., 88: 426-428, 1994.

33. WHITE, N.J. \& BREMAN, J.G. - Paludismo y babesiosis. In: ISSELBACHER, K.J.; BRAUNWALD, E.; WILSON, J.D. et al. Principios de medicina interna. 13. ed. Madrid, Interamericana-Mc Graw Hill, 1994. v. 1, p. 1029-1041.

Received: 19 June 2002

Accepted: 27 September 2002 